\title{
Developmental Trends of Sustainable Bioenergy Systems at TMU Laboratories
}

\author{
Barat Ghobadian \\ Mechanics of Agricultural Machinery Engineering, Tarbiat Modares University (TMU), Tehran, Iran \\ Email: ghobadib@modares.ac.ir
}

Received April 1, 2012; revised May 4, 2012; accepted May 16, 2012

\begin{abstract}
This paper describes a brief review of biodiesel R \& D developmental trends at Tarbiat Modares University (TMU) bioenergy research laboratories (lab.), Tehran, Iran. The developmental trends at includes potential and feasibility study, cultivation of a sample bioenrgy farm, technology innovation and its scale up (patents) for fuel processing, and finally the fuel application in diesel engines. A national investigation was carried out to find out the possible potential of sustainable feedstock for biodiesel production. The results showed that easily available biodiesel feedstock is waste cooking oil with a maximum potential of 750 mil.lit and an approximately 350 mil.lit. of collectable waste cooking oil. A castor oil plant farm was cultivated to harvest castor plant seeds, extract its oil, produce biodiesel fuel and use it in diesel engines. This led to a series of patent and consequently technology innovation from 7 lit. lab. scale to semi-continuous, semi-industrial scale of 2 ton capacity.
\end{abstract}

Keywords: Biomass; Bioenergy; Biofuels; Biodiesel; Feedstocks

\section{Introduction}

The R \& D activities on biodiesel in Iran in general, and at TMU in particular, is considered to be at its infantry stage compared to similar research works carried out throughout the world. Perhaps the first step taken towards the R \& D at TMU on biofuels was the result of an investigation presented at a national conference and published in its proceedings at Tehran, Iran [1]. Later on, a biofuel strategic plan was devised at Tarbiat Modares University (TMU), for bioenergy and biofuel R \& D sustainable system development. One of the objectives in this strategic plan was to establish the laboratories and train the human resources in the form of M.Sc. and Ph.D. students. Consequently, biofuel laboratories were established followed by the development of a biomass and bioenergy strategic plan. These laboratories are today well known as TMU research and development bioenegy laboratories at Tarbiat Modres University, the college of agriculture campus [2]. The biodiesel R \& D activity was part of the biomass and bioenergy R \& D strategic plan. In this case, a number of research works were carried out [3-15] or going on [16-21] in the form of feasibility studies, M.Sc. dissertations and Ph.D. thesis. The results and the findings of the $\mathrm{R} \& \mathrm{D}$ on various topics have been either presented in conferences [22-66] and/or published in journals [67-82]. The biodiesel R \& D activities also resulted in a few number of research patents [83-96].
Finally, the results are being published in the form of a book on biodiesel production and application technology [97]. A close scrutiny of the topics investigated reveals that the subject-vise R \& D activities can be classified as:

- Feasibility study of sustainable feedstock,

- Technology innovation,

- Biodiesel fuel production, and finally

- Fuel application analysis.

\section{The Feasibility Study of Sustainable Feedstock}

Various studies and investigations have revealed that about 70 to 75 percent of the biodiesel fuel cost goes for the feedstock. The feedstock for biodiesel production differs from place to place and from country to country. In Iran, above 90 percent of the edible oil is imported. Moreover the cultivation of inedible plants has not been practiced so far. Therefore, a feasibility study was organized to find out the possible potential feedstock throughout the country [3]. The findings indicated that approximately 750 million liters(m.lit.) of biodiesel could be produced from waste vegetable cooking oils.

This quantity is not fully collectable. The collectable quantity is about 50 percent (350 million liters). The investigation suggested the potential oil plants suggested of Castor oil plant, Jatropha, Oil palm, Microalgae, and rapeseed for future cultivation as energy farms (Figure 1). 


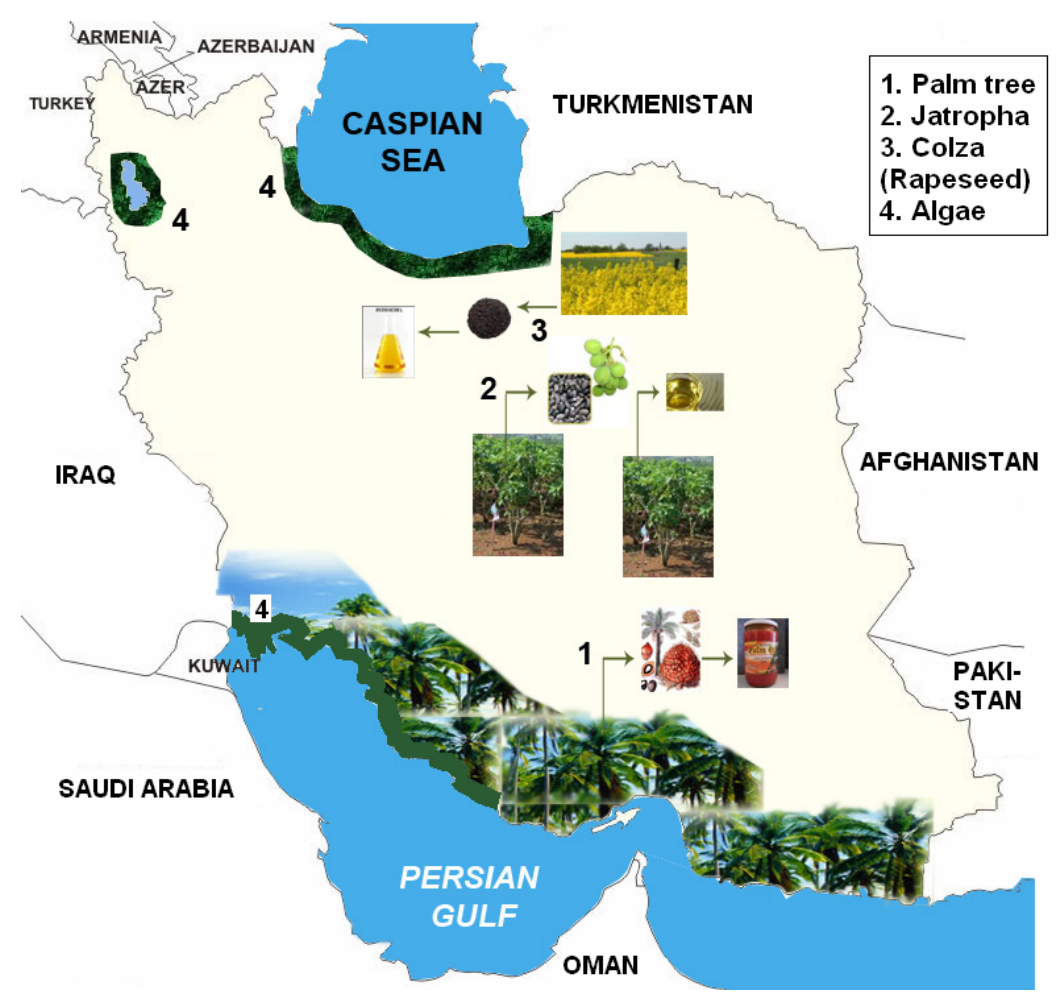

Figure 1. Biodiesel feedstock potential in Iran [3].

\section{Technology Innovation}

One of the key elements in biodiesel fuel production is biodiesel processor systems and biorefineries. A biorefinery in production of biofuels plays similar role and functions as petroleum refinery in the case of petroleum products. Therefore, it was decided to investigate the biodiesel production technologies which start from the grass root aiming at obtaining knowhow and making the technology suitable for local and indigenous conditions. The R \& D was therefore started at laboratory scale, Figure $2[45,48]$. One of the main objectives was to plan for technology innovation from laboratory scale biodiesel processor to semi-industrial scale and then scaling up so that the design parameters could be obtained [46,47].

The designed and fabricated 3 liter capacity laboratory type multifunction biodiesel processor (ILBP3-MF) was used to investigate the effective parameters for the processor design, development and scale up. Several design parameters could be controlled and altered in this handy version biodiesel processor. This portable multifunction processor was used to produce standard biodiesel fuel from a number of feedstock and was named as first generation biodiesel fuel processor at TMU [85]. Figure 3 shows the sustainable system developmental trends and technology innovations at TMU bioenergy research laboratories. This figure shows right from castor sample energy farm to oil extraction and biodiesel production and purification.
At this stage, it was necessary to look for fresh feedstock instead of relying on waste vegetable oils only. This was the time that a small energy farm was established and managed using local castor oil seeds. After harvesting the seeds, then an extruder was designed, fabricated and evaluated for the oil extraction [10,91], followed by the an 80 liter batch type biodiesel fuel processsor design and development, called BDI-80 [4,83]. Then a series of biodiesel processors were designed, developed and tested. The difference between these biodiesel processors lies in the degree of their maturity, as far as the capacity of biodiesel production and purification is concerned. The third generation was semi-continuous

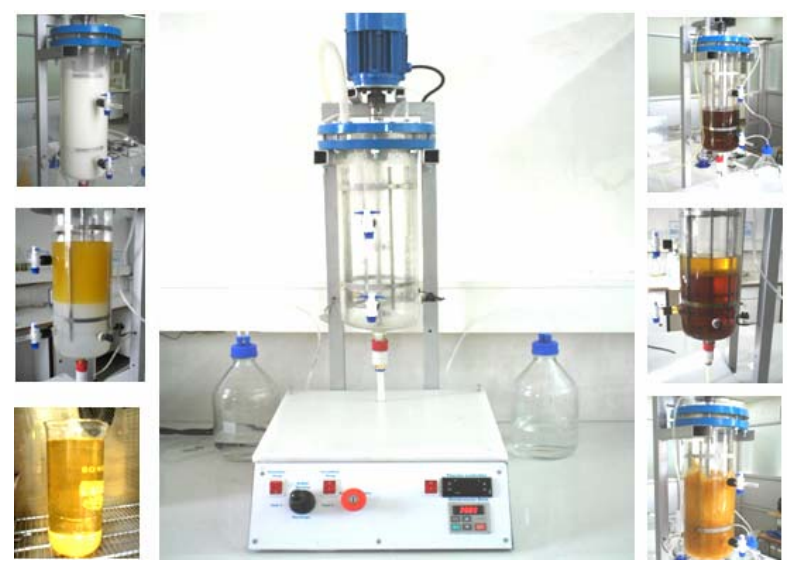

Figure 2. Multifunction laboratory processor $[45,48]$. 

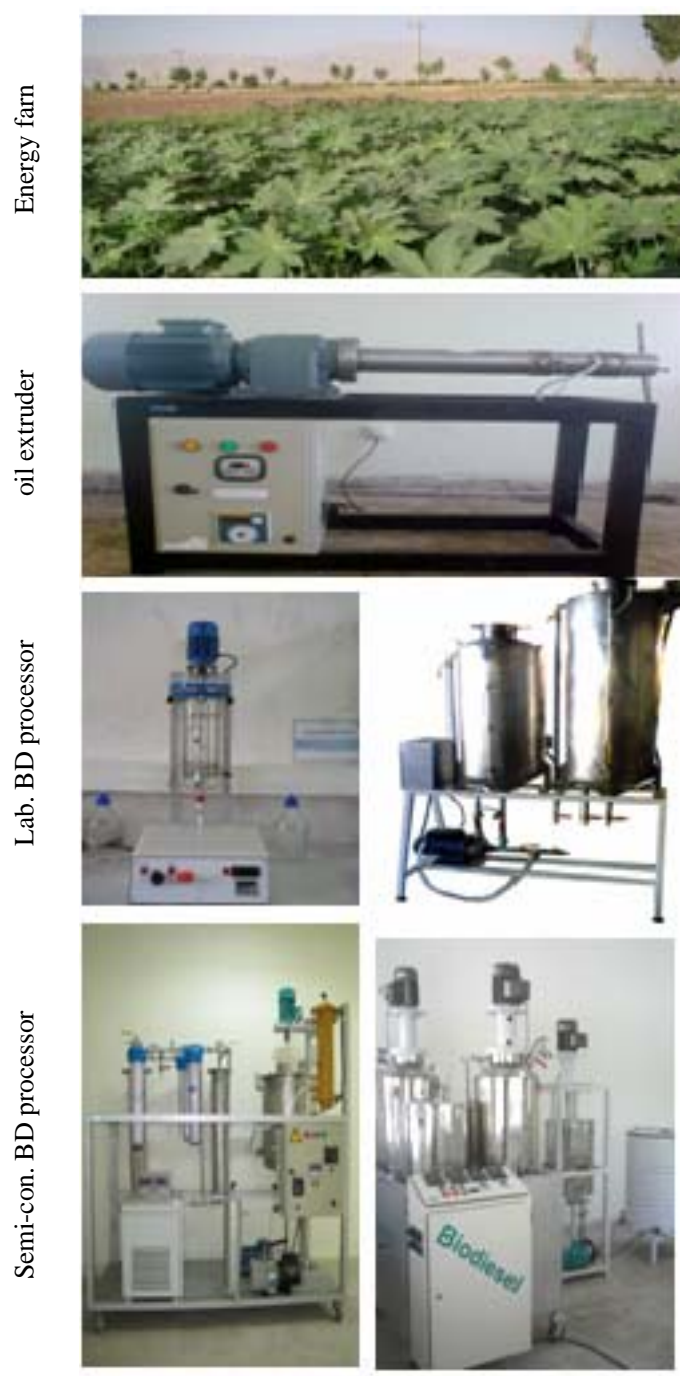

Figure 3. From sustainable feedstock to biodiesel processors technologies [11,51,90].

biodiesel processor $[8,9,87]$. A new version of this type was equipped with biodiesel purification system $[11,90]$. Once the technology developed, then the scale up for mass production is not a very tough job. From laboratory biodiesel processor development of ILBP3-MF to innovation of BDI-80 and then semi-continuous and also then semi-continuous equipped with the purify-cation system, the final goal was the scale up for mass production. Figure 4 shows a 2 ton biodiesel processor (a), along with a glycerol production and purification (b) system $[51,88,89]$.

\section{Biodiesel Fuel Production}

Standard biodiesel fuel was produced from waste cooking oil by transesterification method at TMU biodiesel laboratory and the produced glycerin along with biodiesel was separated (see Figure 5). The main biodiesel

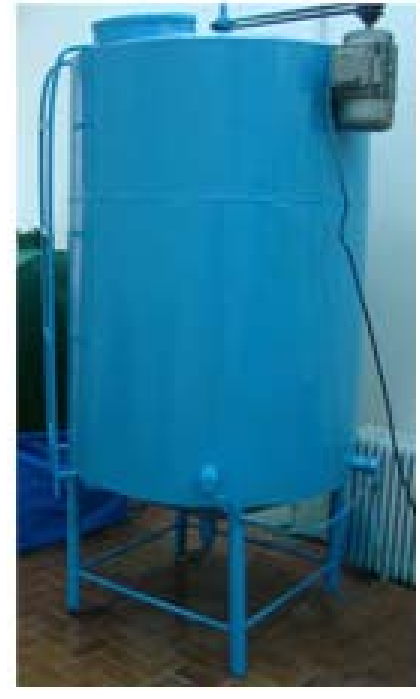

(a)

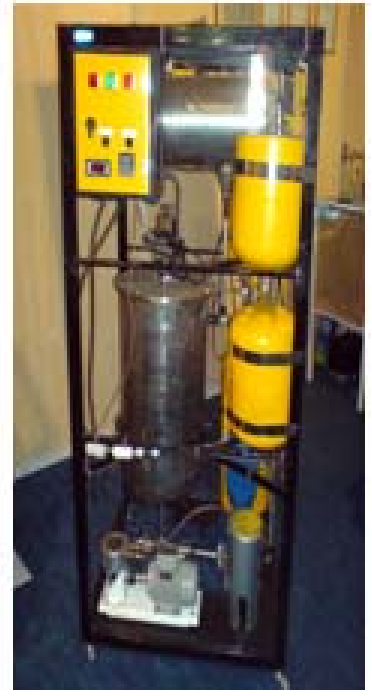

(b)
Figure 4. (a) A 2 ton biodiesel processor and (b) A glycerol purification system $[11,90]$.

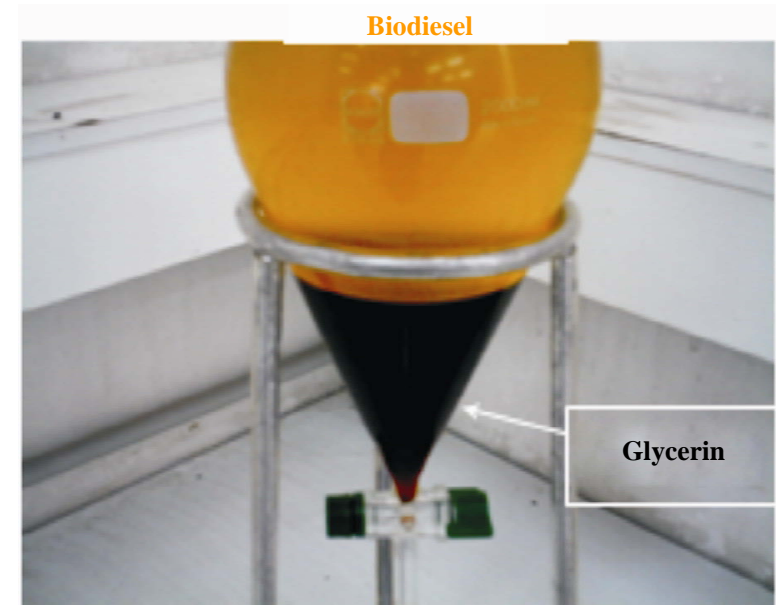

Figure 5. Biodiesel and glycerin separation [4].

fuel properties were determined and compared with ASTM D-6751-09 standard. The produced fuel complied with both ASTM D-6751-09 and EN 14214 standards [4].

The production technology knowhow includes traditional and advanced methods using ultrasonic and microwave $[18,21,55]$. Besides the regular biodiesel production, a new type of fuel called "Diesterol" was also innovated. This new specific term which denotes the mixture of fossil diesel fuel (D), vegetable oil methyl ester called biodiesel (B) and plant derived ethanol (E), was patented [86] and the findings were published [74]. The bioethanol/biodiesel ratio of diesterol was 60/40. Table 1 shows these fuel blends composition.

The cetane number of ethanol is extremely low (5-8) compared with diesel fuel cetane number (47), the cetane 
number of the ethanol-diesel blend fuel reduces signifycantly. Using $6 \%$ ethanol to diesel fuel reduced fuel blend cetane number to 44 , but adding biodiesel improved ethanoldiesel cetane number due to higher cetane number of biodiesel (54).

The obtained pour point of diesel fuel and diesterol is given in Table 2. Diesterol resists low temperature and seems to be more suitable for cold climate. Many conventional diesel fuels must be modified during winter by blending with No. 1 diesel or kerosene, or low temperature flow improving additives, to avoid phase separation or fuel gelling.

Because of very low freezing point of ethanol relative to diesel fuel, it might be expected that ethanol-diesel would have improved low temperature flow properties, as long as the ethanol remains soluble. Solubility of ethanol in diesel fuel is very low especially in low temperatures. Phase separation is occurred when ethanoldiesel blends temperature is reduced. Adding biodiesel to ethanol-diesel solves phase separation problem at lower temperature. Diesel and diesterol pour point is $-2^{\circ} \mathrm{C}$ and $-7^{\circ} \mathrm{C}$ respectively that make diesterol more suitable for cold climate.

If fuel viscosity is low, the leakage will correspond to a power loss for the engine [74]. The other newly developed fuels at TMU bioenergy laboratories are D-series and G-series [14,15,63]. The description of the newly developed advanced hybrid diesel fuels is out of the scope of the present brief review paper.

\section{Fuel Application Analysis}

The standard biodiesel produced was tested both at Megamotor company engine test bed and TMU engine and vehicle application laboratory in Figure 6 [6,7,14,15,74,75]. In this case, engine performance and emissions were

Table 1. The diesterol fuel blends composition.

\begin{tabular}{cccccc}
\hline Fuel fype (\% v) & D & Diesterol & E & B & E/B \\
\hline Diesel & 100 & 90 & 0 & 0 & 0 \\
Bioethanol & 0 & 6 & 100 & 0 & 60 \\
Biodiesel & 0 & 4 & 0 & 100 & 40 \\
Mass (\% oxygen) & 0 & 2 & 34 & 11 & 19.9 \\
\hline
\end{tabular}

Table 2. Pour point, viscosity and flash point of fuels.

\begin{tabular}{cccccc}
\hline Fuel type & Diesterol & $\mathrm{D}$ & $\mathrm{B}$ & $3 / 2 \mathrm{E} / \mathrm{B}$ & $\mathrm{E}$ \\
\hline Pour point $\left({ }^{\circ} \mathrm{C}\right)$ & -7 & -2 & -3 & -9 & $<<50$ \\
Viscosity $\left(\mathrm{mm}^{2} / \mathrm{s}\right)$ & 2.9 & 3.28 & 4.22 & 1.65 & 1.10 \\
Flash point $\left({ }^{\circ} \mathrm{C}\right)$ & 14 & 64 & 187 & 14 & 14 \\
Lubricity $(\mathrm{HFRR})$ & 0.29 & 0.84 & 0.25 & - & - \\
\hline
\end{tabular}

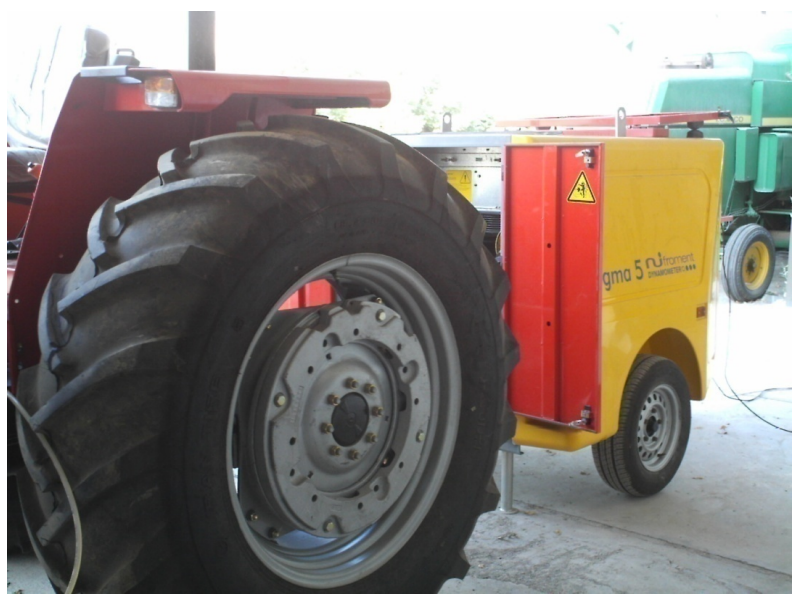

Figure 6. Engine performance analysis $[6,7,14,15]$.

evaluated. Here, diesterol which is a fuel mixture that contains diesel fuel, bioethanol and biodiesel has been used. The diesterol properties such as pour point, viscosity, flash point, copper strip corrosion, ash and sulfur content and cetane number were determined in laboratory. The amount of oxygen content of fuel blends were measured during research work. Experimental results showed that bioethanol, biodiesel and diesel mass oxygen content is $34 \%, 11.01 \%$ and 0.0 respectively.

The amount of oxygen content of bioethanol-biodiesel-diesel mixtures (diesterol) was calculated from following relationship:

$$
M o=0.34 \rho e V e+0.11 \rho b V b
$$

where

$$
\begin{aligned}
& M o=\text { mass of oxygen in blends }(\mathrm{gr}) \\
& \rho e=\text { density of bioethanol }\left(\mathrm{gr} / \mathrm{cm}^{3}\right) \\
& \rho b=\text { density of biodiesel }\left(\mathrm{gr} / \mathrm{cm}^{3}\right) \\
& V e=\text { volume of bioethanol in blends (cc) } \\
& V b=\text { volume of biodiesel in blends (cc) }
\end{aligned}
$$

The engine behavior of the diesterol fuel is quite similar to that of the diesel fuel. A typical diesel engine performance curve with and without diesterol is shown in, in Figure 7. Similarly the $\mathrm{CO}$ and $\mathrm{HC}$ emissions of diesel and diesterol fuels at engine fuel load are shown in, in Figure 8. The conclusion of the findings for the engine performance is that, the biodiesel properties are almost similar to that of petro-diesel. The biodiesel contains oxygen that makes the biodiesel and its blends to burn cleaner in the diesel engine combustion chamber, making biodiesel an environmental friendly fuel.

The concluding remarks for the present paper are the achievements of the biodiesel $\mathrm{R}$ and $\mathrm{D}$ activities at TMU bioenergy research laboratories which include a feasibility study, an strategic plan, 19 dissertations and thesis research works, 44 conference papers, 12 journal papers, 14 patens and a book, besides the technology and fuel innovations. 


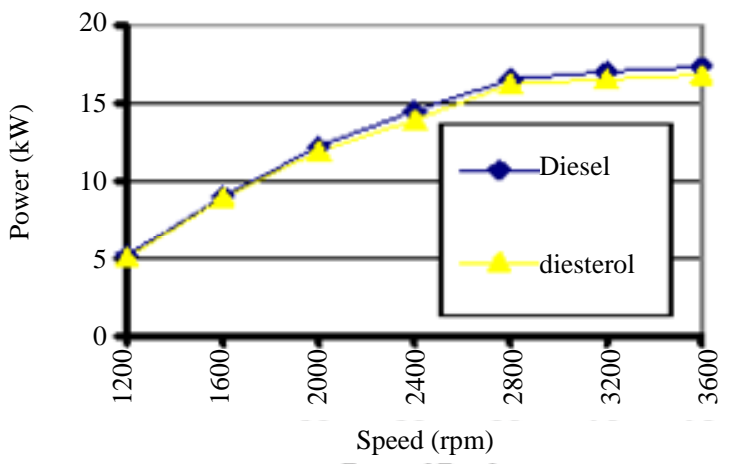

Figure 7. Engine performance with diesterol [74].

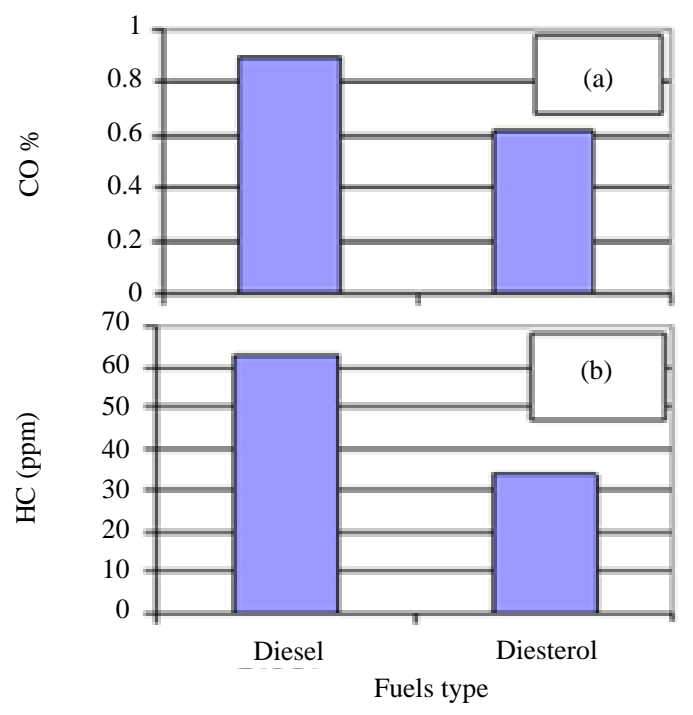

Figure 8. (a) CO and (b) HC emissions of diesel and disterol fuels at engine full load [74,86].

\section{Acknowledgements}

The author would like to thank the Iranian Fuel Conservation Organization (IFCO) of National Iranian Oil Company (NIOC) for the research grant provided to carry out part of this investigation

\section{REFERENCES}

[1] B. Ghobadian, "Design of a Fixed Dome Biogas Plant," The 1st National Biogas Seminar in Iran, Tehran, $3 \mathrm{Au}-$ gust 1996, p. 108.

[2] B. Ghobadian, “Ghobadian, TMU Research and Development Strategic Plan on Biomass and Bioenergy. Internal Report Prepared for Bioenergy Research Laboratory,” Tarbiat Modares University (TMU), Tehran, 2001.

[3] B. Ghobadian, "Biodiesel Production Feasibility Study in Iran: A Project Report,” Tarbiat Modares University (TMU) and Iranian Fuel Conservation Organization (IFCO), Tehran, 2010.

[4] M. Khatamifar, "Design, Development and Evaluation of Biodiesel Processor,” M.Sc. Dissertation, Tarbiat Modares
University (TMU), Tehran, 2006.

[5] A. Mohammadi, "Conceptual Design of a Non-Continuous Process Pilot for Biodiesel Fuel Production from High FFA,” M.Sc. Dissertation, Tarbiat Modares University (TMU), Tehran, 2006.

[6] B. Najafi, "Cobustion Process and Exhaust Emissions of a Dual Fuel Engine Using CNG and Biodiesel Fuels," Ph.D. Thesis, Tarbiat Modares University (TMU), Tehran, 2006.

[7] A. Zenouzi, "Performance Evaluation of MF399 Tractor Using Diesel-Biodiesel Fuel Blends,” M.Sc. Dissertation, Tarbiat Modares University (TMU), Tehran, 2007.

[8] M. F. Nejad, "Biodiesel Processor Waterwashing Tank Improvement,” M.Sc. Dissertation, Tarbiat Modares University (TMU), Tehran, 2007.

[9] H. Bagherpoor, "Reactor Improvement of Biodiesel Processor,” M.Sc. Dissertation, Tarbiat Modares University (TMU), Tehran, 2007.

[10] M. S. Ardebili, "Design, Development and Evaluation of Casto Oil Extractor,” M.Sc. Dissertation, Tarbiat Modares University (TMU), Tehran, 2010.

[11] A. Abbasszadeh, "Investigation of Biodiesel Purification Methods,” M.Sc. Dissertation, Tarbiat Modares University (TMU), Tehran, 2010.

[12] A. Chegeni, "Evaluation of Biodiesel Production from Waste Coocking Oil,” M.Sc. Dissertation, Tarbiat Modares University (TMU), Tehran, 2010.

[13] R. Yahyaie, “Design, Development and Evaluation of Oil Fish Waste Extraction Laboratory Apparatus for Biodiesel Production,” M.Sc. Dissertation, Tarbiat Modares University (TMU), Tehran, 2011.

[14] P. Nematizadeh, "Investigation of Performance and Exhaust Emissins of Two Types of Internal Combustion Engines Using Fossil Fuel and Biofuel Blends,” M.Sc. Dissertation, Tarbiat Modares University (TMU), Tehran, 2011.

[15] M. R. S. Nicharan, "Measurement and Analysis of a Diesel Engine Ignition Delay Using Diesel-Biodiesel Fuel Blends,” Ph.D. Thesis, Tarbiat Modares University (TMU), Tehran, 2010.

[16] S. R. Kondori, “Theoretical Model and Experimental Investigation of the Effect of Fuel Pressure and Injection Timing on the Performance Characteristics of a Diesel Engine Using Biodiesel,” Ph.D. Thesis, Tarbiat Modares University (TMU), Tehran, 2010.

[17] A. Zenouzi, "Design, Development and Evaluation of a Micro Algae Hybrid Seperator System from Its Media to Improve the Biodiesel Energy Balance,” Ph.D. Thesis, Tarbiat Modares University (TMU), Tehran, 2010.

[18] M. Zare, "Investigating Biodiesel Fuel Continuous Production Process by Microwave Irradiation,” M.Sc. Dissertation, Tarbiat Modares University (TMU), Tehran, 2011.

[19] E. Fayyazi, "Biodiesel Fuel Production Using Ultrasonic System,” M.Sc. Dissertation, Tarbiat Modares University (TMU), Tehran, 2011.

[20] S. Y. Moosavi, "Feasibility Study of Biodiesel Production 
from Castor Oil Plant under Density, Cultivar and Sulfur Treatment in Khuzestan Province Climate Conditions,” Ph.D. Thesis, Tarbiat Modares University (TMU), Tehran, 2010.

[21] B. M. Maynagh, "Effect of Ultrasonic System on the Continuous Biodiesel Production,” Ph.D. Thesis, Tarbiat Modares University (TMU), Tehran, 2010.

[22] B. Ghobadian and H. Rahimi, "Biofuels-Past, Present and Future Perspective," The 4th International Iran and Russia Conference, Shahrkord, 8-10 September 2004, p. 22.

[23] B. Ghobadian and M. Khatamifar, "Biodiesel Fuel Production Using Transesterification of Waste Vegetable Oils," Proceedings of the 4th International Conference on Internal Combustion Engines, Tehran, 16-18 November 2005, p. 191.

[24] B. Ghobadian and M. Khatamifar, "Producing Biodiesel from Waste Edible Oils," Proceedings of the 2nd $\mathrm{Na}$ tional Conference on Agricultural Products Losses, Tarbiat Modares University, Tehran, 24 August 2005.

[25] B. Najafi, V. Piroozpanah and B. Ghobadian, "Effects of Biodiesel to Reduce Diesel Engine Pollution," The 1st Combustion Conference of Iran, Tarbiat Modarres University, Tehran, 26-27 February 2005.

[26] A. Mohammadi, M. R. Omidkhah and B. Ghobadian, "Conceptual Design Process for Continuous Production of Biodiesel with High Percentage of Free Fatty Acids Feedstock," The 11th National Congress of Chemical Engineering, Tarbiat Modarres University, Tehran, 7-9 November 2006

[27] G. Najafi, B. Ghobadian and H. Rahimi, "Comparing the Diesel Engine Pollutins Using Waste Oil Biodiesel and Diesel Fuel,” The 3rd Student Conference on Agricultural Machinery Engineering and Mechanization, Shiraz, 2930 April 2007, p. 77.

[28] A. M. Nikbakht, B. Ghobadian and M. Khatamifar, "A Comprehensive Review of Biodiesel Fuel in Iran," The 3rd Student Conference on Agricultural Machinery Engineering and Mechanization, Shiraz, 29-30 April 2007, p. 62.

[29] B. Ghobadian, A. M. Nikbakht and M. Khatamifar, "The Capacity of Using Biodiesel as a Clean Fuel for Sustainable Development Environment,” Tehran University, Tehran, 21 March 2007.

[30] A. Zenouzi and A. Ghobadian, "Comparing the Produced Biodiesel as Renewable Energy from Four Edible Oils,” The 6th National Congress of Energy, Tehran, 22-23 June 2007.

[31] A. Mohammadi, M. R. Omidkhah and B. hobadian, "Design and Optimization of Biodiesel Production Process of Food Waste Industry," The 6th National Congress of Energy, Tehran, 22-23 June 2007.

[32] B. Najafi, V. Piroozpanah and B. Ghobadian, "Experimental Investigation of Performance and Emission Parameters of a Dual Fuel Diesel Engine Using Alternative CNG and Biodiesel Fuels," The 5th Internal Combustion Engines Conference, Tehran, 29 August-1 September 2007, p. 13.

[33] B. Ghobadian and H. Bagherpour, "Comparison of Alkaline and Acidic Methods and Glysryn Extraction from
Waste Oil in Biodiesel Fuel Production Process," The 3rd National Conference on Agricultural Products Losses, Theran, 30 August, p. 559.

[34] B. Ghobadian and M. F. Nejad, "Evaluation of Biodiesel Production Washing Methods from Waste Vegetable Oil," The 3rd National Conference on Agricultural Products Losses, Tehran, 30 August 2007, p. 125.

[35] A. Zenouzi, B. Ghobadian, T. T. Hashjin, M. F. Nejad and H. Bagherpour, "Combustion of Biodiesel from Waste Oil in a 6 Cylinder Perkins Engine,” The 2nd Conference of Combustion, Islamic Azad University of Mashhad, Mashhad, 23-24 February 2007, p. 30.

[36] H. Bagherpour, B. Ghobadian, T. Tavakkoli, T. A. Mohammadi, M. F. Nejad and A. Zenouzi, "Biodiesel Fuel from Waste Oil Using Transesterification,” The 5th $\mathrm{Na}$ tional Congress of Agricultural Engineering and Mechanization, Mashhad, 6-7 August 2008.

[37] M. R. S. Neicharan, B. Ghobadian, T. T. Hashjin and G. Najafi, "Experimental Investigation of Performance Parameters in a Diesel Engine Using Biodiesel Fuel," The 3rd Combustion Conference of Iran, Amir Kabir University, Tehran, 2-3 February 2010, p. 93.

[38] M. S. Ardebili, B. Ghobadian and T. T. Hashjin, "Determination of the Castor Oil Apparent Elastic Coefficient to be Used for Optimum Processing," 1st Scientific Conference on the Developmentt of the Medicne Plants, Tehran, March 2009.

[39] M. S. Ardebili, B. Ghobadian, M. Azadbakht and A. Nasiri, "Energy Balance of Canola in Golestan Provine for Biodiesel Fuel Production," The 3rd Combustion Conference of Iran, Amir Kabir University, Tehran, 2-3 February 2010, p. 153.

[40] B. Ghobadian, H. Rahimi and M. Khatamifar, "Evaluation of Engine Performance Using Net Diesel Fuel and Biofuel Blends," The 1st Combustion Conference of Iran (CCI1), Tarbiat Modares University, Tehran, 15-16 February 2006, p. 71.

[41] B. Ghobadian, G. Najafi, H. Rahimi and M. Khatamifar, "Comprehensive Evaluation of Engine Performance with Diesel and Biodiesel Fuel Blends," The 3rd International Bioenergy Conference and Exhibition, Finland, 3-6 September 2007.

[42] T. Yusaf, G. Najafi, B. Ghobadian, B. Najafi and V. Pirouzpanah, "Experimental Investigation of Performance and Emission Parameters of Small Diesel Engine Using CNG and Biodiesel,” The 13th Small Engine Technology Conference, Toki Messe, Niigata Convention Center, Niigata, 30 October-1 November 2007.

[43] B. Ghobadian, H. Rahimi and M. Khatamifar, "Experimental Evaluation of Engine Performance Using Typical Diesterol," The International Congress on Biodiesel: The Science and the Technology, Vienna, 5-8 November 2007.

[44] B. Ghobadian, M. Khatamifar and H. Rahimi, "Design, Fabrication and Evaluation of a Patent Biodiesel Processor," The International Congress on Biodiesel: The Science and the Technology, Vienna, 5-8 November 2007.

[45] A. Zenouzi and B. Ghobadian, "Design and Fabrication of a Multifunction Biodiesel Processor," The Interna- 
tional Congress on Biodiesel: The Science and the Technology, Vienna, 5-8 November 2007.

[46] A. Mohammadi, M. R. Omidkhah and B. Ghobadian, "Optimization of Biodiesel Production from High Free Fatty Acid Feedstocks (Part I: Continuous Process),” The International Congress on Biodiesel: The Science and the Technology, Vienna, 5-8 November 2007.

[47] A. Mohammadi, M. R. Omidkhah and B. Ghobadian, "Optimization of Biodiesel Production from High Free Fatty Acid Feedstocks (Part II: Batch/Semi-Continuous Process)," The International Congress on Biodiesel: The Science and the Technology, Vienna, 5-8 November 2007.

[48] A. Zenouzi and B. Ghobadian, "Design and Development of a Biodiesel Processor for Providing FFV's Refrence Fuel," The 5th Conference on Internal Combustion Engines, Tehran, November 20-22 2007, 2 p.

[49] A. Zenouzi, M. Safiadin., B. Ghobadian and T. T. Hashjin, "Optimization of Biodiesel and Diesel Blend Ratio for MF399 Tractor Engine Using Genetic Algorithms,” The 2nd International Congress on Biodiesel: The Science and the Technologies, Munch, 15-17 November 2009.

[50] A. Zenouzi, A. Mohammadi, B. Ghobadian and S. Minaee, "Flexible Batch Pilot Plant for Glycerol Purification in the Biodiesel Production Process l," The 2nd International Congress on Biodiesel: The Science and the Technologies, Munch, 15-17 November 2009.

[51] B. Ghobadian, "A Comprehensive Review of the Biodiesel Production and Purification Technologies in Iran," The 2nd International Congress on Biodiesel: The Science and the Technologies, Munch, 15-17 November 2009.

[52] M. R. S. Neicharan, B. Ghobadian and T. T. Hashjin, "Effects of Biodiesel-Diesel Blended Fuels on Diesel Engine Ignition Delay,” The 6th International Conference on Internal Combustion Engines, Olympic Hotel, Tehran, 17-19 November 2009, p. 67.

[53] B. Ghobadian, "Biodiesel Production Feasibility Study in Iran: A Project Report,” Tarbiat Modares University (TMU), Iranian Fuel Conservation Organization (IFCO), Tehran, 2010.

[54] B. Ghobadian, "Liquid Biofuels Potential and Outlook in Iran,” The 13th Oil and Gas Conference on Energy Management, Policies and Experiences, Olympic Hotel, Tehran, 30 November-1 December 2008.

[55] B. Ghobadian, "Enhancing Biodiesel Production from Waste Cooking Oil with Ultrasonics,” The 10th International on Sustainable Energy Technologies, Kumburgaz, Istanbul, 4-7 September 2011, Article ID: 367.

[56] B. Ghobadian, "Potential of Biodiesel Production from WVO and SVO in Iran,” The 10th International on Sustainable Energy Technologies, Kumburgaz, Istanbul, 4-7 September 2011, Article ID: 279.

[57] G. Najafi, B. Ghobadian and T. Yusaf, "Biofuel from Microalgae: Alternative, Sustainable and Renewable Fuel," The 10th International on Sustainable Energy Technologies, Kumburgaz, Istanbul, 4-7 September 2011, Article ID: 168.

[58] A. A. Mayvan, B. Ghobadian and G. Najafi, "Current
Biodiesel Production Technologies: A Comparative Review," The 10th International Conference on Sustainable Energy Technologies, Kumburgaz, Istanbul, 4-7 September 2011, Article ID: 333.

[59] A. A. Mayvan, B. Ghobadian, G. Najafi and M. R. Omidkhah, "Analytical and FEM Design of Mixing System in STR Biodiesel Production,” The 10th International on Sustainable Energy Technologies, Kumburgaz, Istanbul, 4-7 September 2011, Article ID: 319.

[60] A. A. Mayvan, B. Ghobadian, G. Najafi, M. R. Omidkhah, "Design, Fabrication and Evaluation of a Novel Biodiesel Processor System,” The 10th International on Sustainable Energy Technologies, Kumburgaz, Istanbul, 4-7 September 2011, Article ID: 320.

[61] A. Abbaszadeh, B. Ghobadian and G. Najafi, "High Voltage/Low Amperage Current for Separation of Crude Glycerin from Biodiesel," The 10th International on Sustainable Energy Technologies, Kumburgaz, Istanbul, 4-7 September 2011, Article ID: 351.

[62] S. Rostami, L. Savadkouhi, B. Ghobadian and M. Kiani, "Effect of Injection Pressure on Brake Thermal Efficiency and BSFC in a DI Diesel Engine Using Biodiesel,” The 10th International on Sustainable Energy Technologies, Kumburgaz, Istanbul, 4-7 September 2011, Article ID: 323.

[63] P. Nematizade, B. Ghobadian and G. Najafi, "G-Series: As an Environmental Friendly Hybrid Fossil-Bio Transportation Fuel," The 10th International on Sustainable Energy Technologies, Kumburgaz, Istanbul, 4-7 September 2011, Article ID: 202.

[64] P. Nematizade, B. Ghobadian, G. Najafi and M. S. Ardebili, "Optimization of a Few Fossil Fuels and Liquid Biofuel Blend Properties Using Genetic Algorithm,” The 10th International on Sustainable Energy Technologies, Kumburgaz, Istanbul, 4-7 September 2011, Article ID: 373.

[65] M. S. Ardebili, B. Ghobadian, G. Najafi and A. Chegeni, "Biodiesel Production Potential from Edible Oil Seeds in Iran,” The 10th International on Sustainable Energy Technologies, Kumburgaz, Istanbul, 4-7 September 2011, Article ID: 181.

[66] M. Ghafoori, M. Layeghi, B. Ghobadian, G. Najafi and A. Rashidi, "Effects of Nano-Particles on the Combustion Performance of a Diesel Engine Using Biodiesel-Diesel Blended Fuel,” The 10th International Conference on Sustainable Energy Technologies, Kumbergaz, Istanbul, 4-7 September 2011, Article ID: 396.

[67] B. Ghobadian and M. Khatamifar, "Biodiesel Full Production Using Transesterification of Waste Vegetable Oils,” The Journal of Engine Research, Vol. 8-9, 2006, pp. 24-35.

[68] G. Najafi, B. Ghobadian, A. M. Nikbakht and H. Rahimi, "Compression Ignition Engine Performance Analysis Using a Mixture of Diesel Fuel-Biodiesel with Artificial neural Networks Method," Journal of the Engine Research, Vol. 10-11, 2006, pp. 6-15.

[69] B. Najafi, V. P. Panah and B. Ghobadian, "Experimental Study of Performance and Emission Parameters of Diesel Engine Using Alternative Biodiesel Fuel,” Modares Jour- 
nal of Engineering, No. 28, 2007, pp. 79-91.

[70] B. Najafi, V. Pirouzpanah, B. Ghobadian, G. Najafi and T. Yusaf, "Experimental Investigation of Performance and Emission Parameters of a Small Diesel Engine Using CNG and Biodiesel. SAE and JSAE Transactions," SAE Paper, 2007, Article ID: 2007-32-0075.

[71] B. Ghobadian, T. T. Hashjin and H. Rahimi, "Production of Bio Ethanol and Sunflower Methyl Ester and Investigation of Fuel Blend Properties,” Journal of Agricultural Science and Technology, Vol. 10, No. 3, 2008, pp. 225232.

[72] A. Zonouzi, B. Ghobadian, T. T. Hashjin, M. F. Nejad and H. Bagherpour, "The Effect of Diesel and Biodiesel Fuel Blends from Waste Cooking Oils on CI Engine Performance," Journal of Fuel and Combustion Research, Vol. 1, No. 1, 2008, pp. 53-59.

[73] M. F. Nejad, B. Ghobadian, T. T. Hashjin, B. Bagherpour and A. Zonouzi, "Study Effective Leaching Parameters Biodiesel Fuel,” Journal of Biosystem Engineering, Vol. 40, No. 2, 2009, pp. 147-154.

[74] H. Rahimi, B. Ghobadian, T. Yusaf, G. Najafi and M. Khatamifar, "Diesterol: An Environment Friendly IC Engine Fuel,” Journal of Renewable Energy, Vol. 34, No. 1, 2009, pp 335-342. doi:10.1016/j.renene.2008.04.031

[75] B. Ghobadian, H. Rahimi, A. M. Nikbakht, G. Najafi and T. Yusaf, "Diesel Engine Performance and Exhaust Emission Analysis Using Waste Cooking Biodiesel Fuel with an Artificial Neural Network," Journal of Renewable Energy, Vol. 34, No. 4, 2009, pp. 976-982. doi:10.1016/j.renene.2008.08.008

[76] M. R. S. Neicharan, B. Ghobadian, T. T. Hashjin and R. K. Saraie, "An Experimental Investigation of a Diesel Engine Ignition Delay Using Biodiesel and Diesel Fuels,” Journal of Fuel and Combustion, Vol. 2, No. 1, 2009, pp. 55-68.

[77] M. R. S. Neicharan, B. Ghobadian, T. T. Hashjin and G. Najafi, "Experimental Investigation of the Performance Parameters of a Diesel Engine Using Biodiesel Fuel," Journal of the Engine Research, Vol. 16, 2009, pp. 29-35.

[78] H. Bagherpour, B. Ghobadian, T. T. Hashjin, A. Mohammadi, M. F. Nejad and A. Zonouzi, "Optimization of Effective Parameters in Production of Biodiesel Fuel Using Transesterification,” Journal of Biosystem Engineering Journal, Vol. 40, No. 1, 2010, pp. 37-43.

[79] A. Zonouzi, B. Ghobadian and T. T. Hashjin, "The Effect of Waste Oil Methyl Ester on Tractor Engine Performance,” Modares Journal of Engineering, Vol. 2, 2010, pp 89-99.

[80] M. S. Ardebili, B. Ghobadian, G. Najafi and A. Chegeni, "Biodiesel Production Potential from Edible Oil Seeds in Iran,” Journal of Renewable and Sustainable Energy Reviews, Vol. 15, No. 6, 2011, pp. 3041-3044. doi:10.1016/j.rser.2011.03.004
[81] G. Najafia, B. Ghobadiana and T. Yusaf, “Algae as a Sustainable Energy Source for Biofuel Production in Iran: A case study," Journal of Renewable and Sustainable Energy Reviews, Vol. 15, No. 8, 2011, pp. 3870-3876.

[82] M. S. Ardebili, B. Ghobadian, T. T. Hashjin and G. Najafi, "Determining Mechanical Properties of Castor Seed (Ricinus communis L.) to Design and Fabricate of Oil Extraction Machine," Journal of Agricultural Science and Technology (JAST), 2011, under press.

[83] M. Khatamifar and B. Ghobadian, "Biodiesel Processor, BDI-80,” Iranian Patent No. 36781, 2006.

[84] M. Khatamifar and H. Rahimi, "Biodiesel Processor for Rural Areas,” Iranian Patent No. 38714, 2006.

[85] A. Zenouzi, B. Ghobadian and M. Khatamifar, "Full Automatic Research Apparatus and Multi-Function,” Iranian Patent No. 39373, 2006.

[86] H. Rahimi, B. Ghobadian and M. Khatamifar, "Diesterol Fuel,” Iranian Patent No. 39407, 2006.

[87] M. Feizollahnejad, H. Bagherpour, B. Ghobadian and A. Zenouzi, "Semi-Continuous Process of Biodiesel Fuel Processor,” Iranian Patent No. 50380, 2008.

[88] A. Zenouzi, B. Ghobadian, A. Mohammadi and S. Minaee, "Glycerin Purification Apparatus from Waste Vegetable Oil,” Iranian Patent No. 56463, 2008.

[89] A. A. Maivan, A. Zenouzi, M. Feizollahnejad and B. Ghobadian, "Batch Types Two Tons Biodiesel Processor,” Iranian Patent No. 63670, 2009.

[90] A. A. Myvan and B. Ghobadian, "The Dual Purpose Biodiesel Production and Purification,” Iranian Patent No. 63672, 2009.

[91] M. S. Ardebili and B. Ghobadian, "Laboratory Oil Exteruder Machine with Variable Speed and Temperature," Iranian Patent No. 6363476, 2009.

[92] A. Zenouzi, B. Ghobadian and M. A. Hejazi, "Micro Algae Separation by Electric Current,” Iranian Patent No. 68595, 2010.

[93] A. Zenouzi, B. Ghobadian and M. A. Hejazi, "Micro Algae Hybrid Harvesting Machine,” Iranian Patent No. 68598, 2010.

[94] M. Ghafori and B. Ghobadian, "Bio-Nano-Carbon Fuel for Diesel Engines,” Iranian Patent No. 67896, 2010.

[95] M. Ghafori and B. Ghobadian, "Bio-Nano-Silver Fuel for Diesel Engines,” Iranian Patent No. 67897, 2010.

[96] R. Yahyaee and B. Ghobadian, “The Oil Extracting Machine from Waste Fish for Biodiesel Production,” Iranian Patent No. 70290, 2011.

[97] B. Ghobadian, "Biodiel Production and Application Technology,” Tarbiat Modares Press, Tehran, 2012. 